\title{
The brain-gain game
}

\section{Singapore has made impressive progress towards putting science at the centre of its economy - but can it afford to continue on its trajectory?}

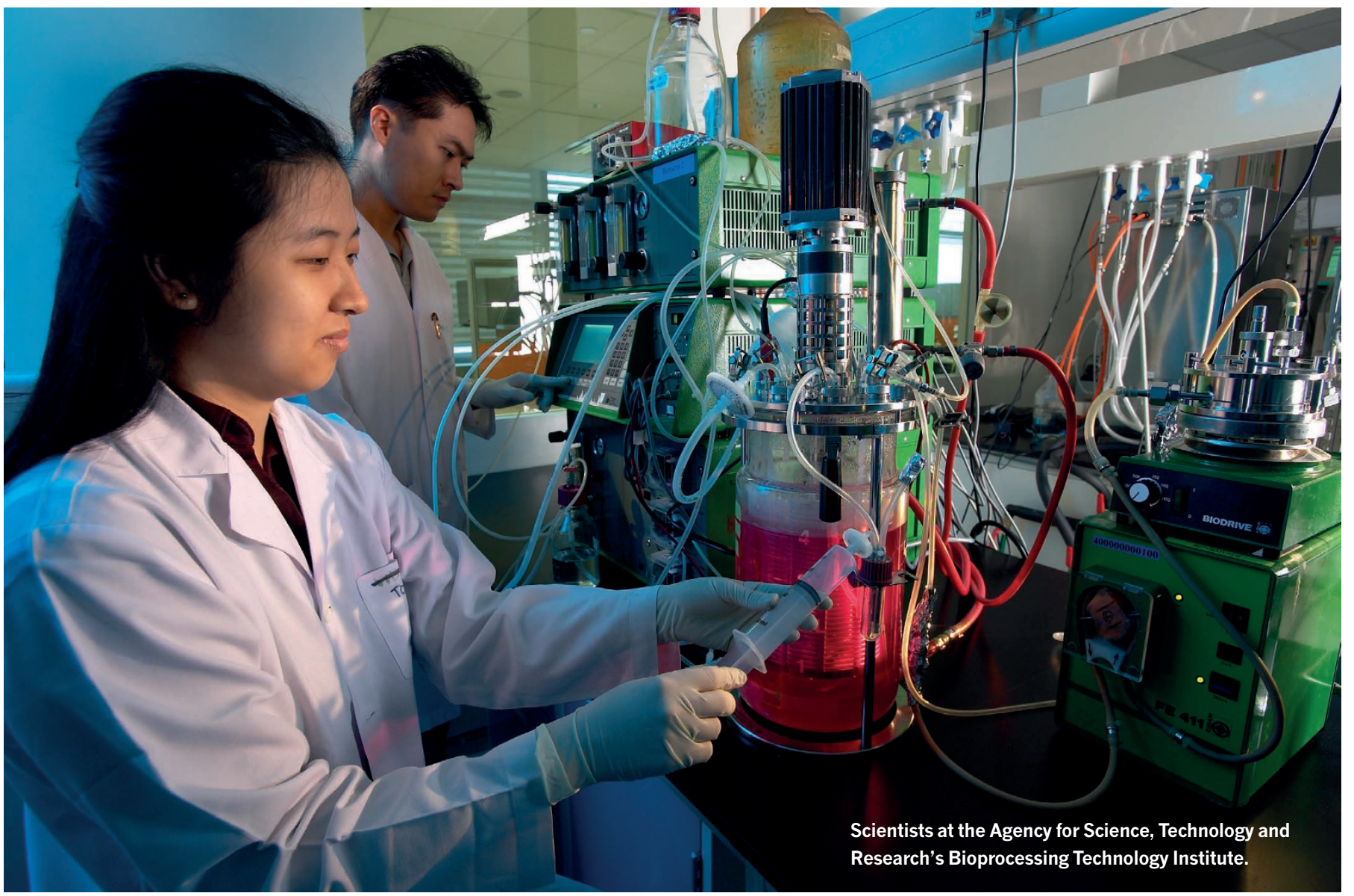

\section{BY ANNABEL MCGILVRAY}

A little over a kilometre off the southern tip of the Malay Peninsula sits a plot of land just 42 kilometres across and 23 kilometres wide. The main island of Singapore is half the size of Los Angeles, with limited natural resources - certainly not enough to cater for its 5 million inhabitants.

Faced with global competition in its traditional industries, 25 years ago Singapore began to pursue a future as an Asian research hub, putting science and technology at the centre of its economy. This was an ambitious goal for a country without an established research culture. But driven by necessity, and generous government funding, Singapore has drawn some of the world's leading scientists, sciencedriven corporations and research institutions to set up labs either alone or in partnership with local universities, businesses and government.

In many respects, the country is succeeding in achieving its research and development (R\&D) goal. It is home to the two highestranked universities in Asia; it has among the strongest industry-university links in the developed world, as determined by the World Economic Forum; it has become a leader in water-processing technology, exporting it to the rest of the world; it is an electronics industry powerhouse, including a centre for superconductor development and manufacturing; and it is rapidly establishing itself as a hotspot for biomedical science.

Despite this, some are questioning whether the government money that has poured into science is generating sufficient bounty in terms of jobs and national income to justify the largesse. Singapore's gross domestic product (GDP) hovers at around $\$ \$ 410$ billion (US $\$ 304$ billion). More than $\mathrm{S} \$ 35$ billion has been allocated by the government to foster home-grown science and technology since 2000. Earlier this year the government promised a further $\mathrm{S} \$ 19$ billion between now and 2020 with the slogan "Winning the Future". Singapore is now one of the bigger spenders on research, with $2.2 \%$ of GDP going towards R\&D in 2014.

But some scientists and funders fear that translation of this research may be happening too slowly and in the wrong parts of the economy to support the continued growth in funding. Although Singapore's multinationals and large local enterprises have done very well, the small- to medium-sized enterprises that employ $70 \%$ of the country's workforce, have yet to incorporate R\&D into their businesses in a substantial way. The Organisation for Economic Co-operation and Development (OECD) has suggested that this may be because of a national aversion to risk-taking. But science leaders now fear that public support for $\mathrm{R} \& \mathrm{D}$ spending and the country's aspirations to become a science-led economy may be dwindling.

"We see science and technology as a very 
important pillar in our future economic growth," says Teck Seng Low, head of Singapore's science funding agency, the National Research Foundation (NRF). Moreover, he says, these endeavours are key to "providing us with solution options to our national challenges".

\section{NATIONAL CHALLENGES}

Water scarcity is a continual problem in Singapore. The city-state has no rivers of substantial size and is dependent on importing water from Malaysia. The NRF has invested heavily in water research, and Singapore is now one of the world leaders in the field, particularly when it comes to the development of membranes for reverse osmosis, desalination, filtering and, more recently, for an innovative approach known as forward osmosis. The country hosts 180 companies involved in water management and is home to 28 research centres focused on water.

The Nanyang Environment and Water Research Institute (NEWRI) was established in 2008 as part of Nanyang Technological University (NTU), with the support of the NRF. NEWRI is one of the world leaders in water research and has been instrumental in the development of forward osmosis. This low-energy osmosis technique uses variations in the concentrations of liquids to draw small molecules such as water through fine membranes, leaving impurities behind. It requires much less energy than reverse osmosis and will potentially be a sustainable and costsaving technology. As part of a project funded by a $\$ \$ 2.5$ million NRF grant, Darco Water Technologies in Sin-

\section{"Singapore doesn't have a long academic tradition, so science and research is fairly new."}

and research institutes and research-intensive industries with global reach.

\section{BIOPOLIS AND BEYOND}

One of the country's research priorities is to become a global player in the biomedical sciences. The drug-development pipeline is one of the longest and most treacherous for translating research into tangible economic outcomes, but Singapore has established itself as a major player. Each year the Agency for Science, Technology and Research (A*STAR) runs about 30 new projects with international pharmaceutical companies. And pharma giants such as Abbott, MSD, Novartis and Pfizer have all set up production facilities in Singapore. In 2015, Chugai Pharmaceutical announced it would invest an additional \$ \$476 million in its research facilities in Singapore.

The centrepiece of Singapore's biomedical push is Biopolis, a research hub established in 2003. Biopolis is home to A*STAR's Institute of Bioengineering and Nanotechnology. Earlier this year, researchers from the institute, in collaboration with computing giant IBM, described a giant molecule - a hyperbranched amine-based polymer - with the capacity to help immune cells defend against a broad range of viruses, including Ebola, Dengue and Marburg, by rendering the viruses unable to replicate (K. Ichiyama et al. Macromolecules 49, 2618-2629; 2016). Although it is early days, the development could be used to protect against these deadly diseases. But even if all goes smoothly, commercial production could be a decade away.

This lengthy wait is part of science, but it is slowing down the country's trajectory to a science-led economy. The innate weaknesses of Singapore's economy - a small domestic market, a reliance on international trade, a scarcity of natural resources and a high cost of labour and property in comparison to the rest of Southeast Asia - make science a necessity for future prosperity, says Yuen Ping Ho, associate director of research at the National

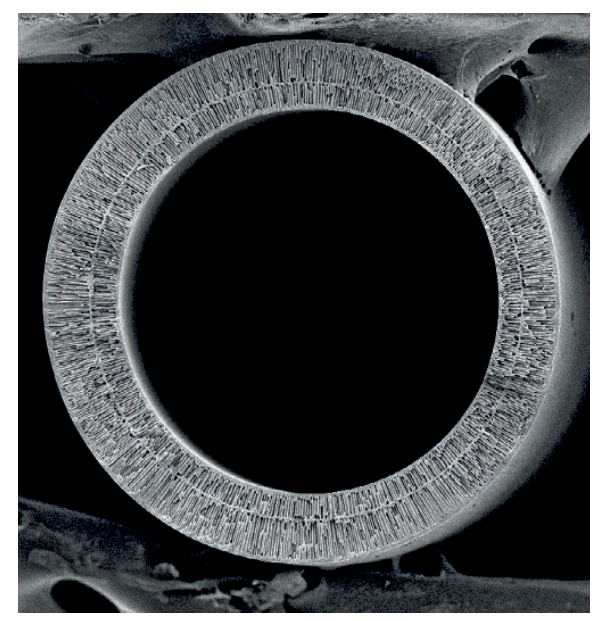

A cross-section of a forward-osmosis membrane, which researchers at NEWRI helped to develop.
University of Singapore's Entrepreneurship Centre. "To remain competitive in the face of these constraints, the economy has been moving towards a more knowledge-based structure," Ho says. "Science and technology is essential in this transition in two ways - doing things better, and doing new things."

But Ho's research shows that the impact of R\&D on Singapore's economic growth hasn't been as great as in other members of the OECD (Y. P. Ho et al. Singapore Econ. Rev. 54, $1 ; 2009)$. Ho attributes this to the country's relatively recent embrace of science investment. Although strong links have been established between researchers and large industry corporations, there are still few partnerships with small to medium enterprises. These companies are the bulk of the country's economy and are where productivity improvements and product disruption could have greatest effect.

\section{CLOUDS ON THE HORIZON}

As NTU president, Bertil Andersson has seen first hand the dramatic effect that the government's science push has had on Singapore's research capacity. The most important development, he says, has been the ability to attract the best talent from around the world and to lift the education standards in schools and universities. It's what he calls the 'brain-gain game.' "Singapore doesn't have a long academic tradition, so science and research is fairly new," Andersson says. The country wants a return on its investment, a goal that he acknowledges is still a challenge. "I am confident that it will happen, but it may take some time."

But politicians can be impatient. Pointed questions are being asked, says Low. "All of them are asking 'Now that we have invested $\$$ \$40-odd billion in the last 25 years and $\$ \$ 20$ billion in the next 5 years. What can we expect?"

Recent figures are encouraging. They show that business expenditure on $R \& D$ reached a new high of $\$ \$ 5.2$ billion in 2014, up from $\$ \$ 3.9$ billion in 2010 . The greatest increase came from small- and medium-sized companies, which spent $\mathrm{S} \$ 800$ million. Activity that suggests companies are more willing to take risks.

Despite these signs that Singapore's domestic businesses are responding positively to the stimulus of long-term generous government investment in science, Low says that government funding will not continue to increase in the same way it has for the past 25 years. $\mathrm{He}$ thinks that as the science ecosystem of Singapore matures, government support will plateau where it is at around $1 \%$ of GDP. If the dynamic island at the end of the Malay Peninsula is going to continue its progress towards a science-led economy, private funds will need to fill the gap. "We have this ecosystem in place," Low says. "But it is what we make of it that will allow us to see some measure of success."

Annabel McGilvray is a freelance science writer in Sydney, Australia. to threaten the creation of a knowledge ecosystem comprised of top-ranked universities 